Supplement of Solid Earth, 10, 149-175, 2019

https://doi.org/10.5194/se-10-149-2019-supplement

(C) Author(s) 2019. This work is distributed under

the Creative Commons Attribution 4.0 License.

(c) (1)

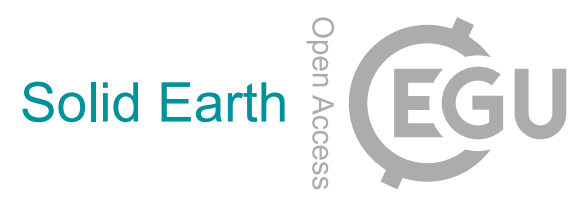

Supplement of

\title{
Tectono-thermal evolution of Oman's Mesozoic passive continental mar- gin under the obducting Semail Ophiolite: a case study of Jebel Akhdar, Oman
}

Arne Grobe et al.

Correspondence to: Arne Grobe (arne.grobe@rwth-aachen.de)

The copyright of individual parts of the supplement might differ from the CC BY 4.0 License. 
ELECTRONIC SUPPLEMENTARY MATERIAL

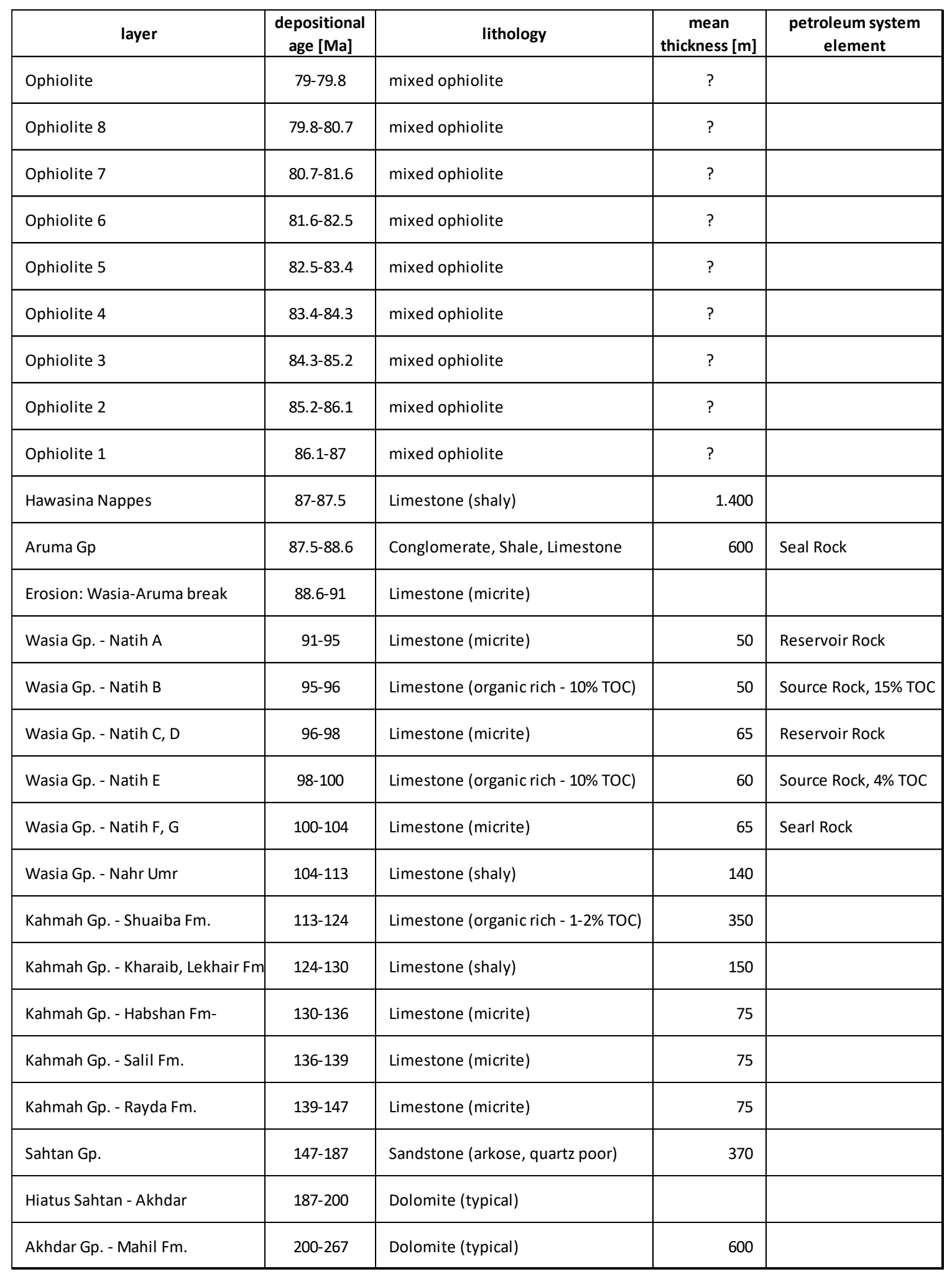

Figure S1: Stratigraphic age assignment used for the PetroMod 2D basin model. Outlined are the used depositional ages lithologies and mean thicknesses. The Wasia-Aruma break fully eroded the Natih Fm. in the northern part of the 2D transect, with a gradually decrease of erosion towards the southern flank of the present-day Jebel Akhdar. 


\begin{tabular}{|c|c|c|c|c|c|c|}
\hline \multirow[t]{2}{*}{ lithology } & \multirow{2}{*}{$\frac{\text { density }}{\left[\mathrm{kg} / \mathrm{m}^{3}\right]}$} & \multirow{2}{*}{$\begin{array}{c}\text { max. } \\
\text { compressibility } \\
{\left[\mathrm{Gpa}^{-1}\right]}\end{array}$} & \multicolumn{2}{|c|}{ thermal conductivity } & \multicolumn{2}{|c|}{ heat capacity } \\
\hline & & & $\begin{array}{c}\text { at } 20^{\circ} \mathrm{C} \\
{[\mathrm{W} / \mathrm{m} / \mathrm{K}]}\end{array}$ & $\begin{array}{l}\text { at } 100^{\circ} \mathrm{C} \\
{[\mathrm{W} / \mathrm{m} / \mathrm{K}]}\end{array}$ & $\begin{array}{c}\text { at } 20^{\circ} \mathrm{C} \\
{[\mathrm{kcal} / \mathrm{kg} / \mathrm{K}]}\end{array}$ & $\begin{array}{c}\text { at } 100^{\circ} \mathrm{C} \\
{[\mathrm{kcal} / \mathrm{kg} / \mathrm{K}]}\end{array}$ \\
\hline $\begin{array}{l}\text { ophiolite mixed after Rioux et al. } \\
\text { 2013* }\end{array}$ & 3076 & - & 3,36 & 2,96 & 0,18 & 0,21 \\
\hline $\begin{array}{l}\text { serpentinized ophiolite mixed after } \\
\text { Rioux et al. } 2013\end{array}$ & 3012 & - & 2,28 & 2,16 & 0,19 & 0,22 \\
\hline $\begin{array}{l}\text { ophiolite mixed after Searle \& Cox } \\
2002^{* *}\end{array}$ & 3133 & - & 3,50 & 3,07 & 0,18 & 0,20 \\
\hline $\begin{array}{l}\text { serpentinized ophiolite mixed after } \\
\text { Searle \& Cox } 2002\end{array}$ & 3069 & - & 2,38 & 2,24 & 0,19 & 0,22 \\
\hline Limestone (shaly) & 2730 & 68,65 & 2,30 & 2,18 & 0,20 & 0,23 \\
\hline Limestone (organic rich - 1-2\% TOC) & 2710 & 86,51 & 2,63 & 2,42 & 0,20 & 0,23 \\
\hline Limestone (organic rich - 10\% TOC) & 2550 & 95,68 & 1,45 & 1,55 & 0,20 & 0,23 \\
\hline Limestone (ooid grainstone) & 2740 & 0,20 & 3,00 & 2,69 & 0,20 & 0,23 \\
\hline Sandstone (arkose, quartz rich) & 2690 & 26,71 & 4,05 & 3,46 & 0,21 & 0,24 \\
\hline Conglomerate (typical) & 2700 & 14,21 & 2,30 & 2,18 & 0,20 & 0,23 \\
\hline
\end{tabular}

* Peridotite 64.4\%, Gabbro 20\%, Basalt 5.7\%Quarztonalite 4.6\%, , Amphibolite 3\%, Granodiorite 2.3\%

** Peridotite 64.4\%, Gabbro 16.7\%, Dunite 11.1\%, Basalt 5.6\%, Amphibolite $2.2 \%$

Figure S2: Petrophysical parameters of the used lithologies in the numerical basin model.
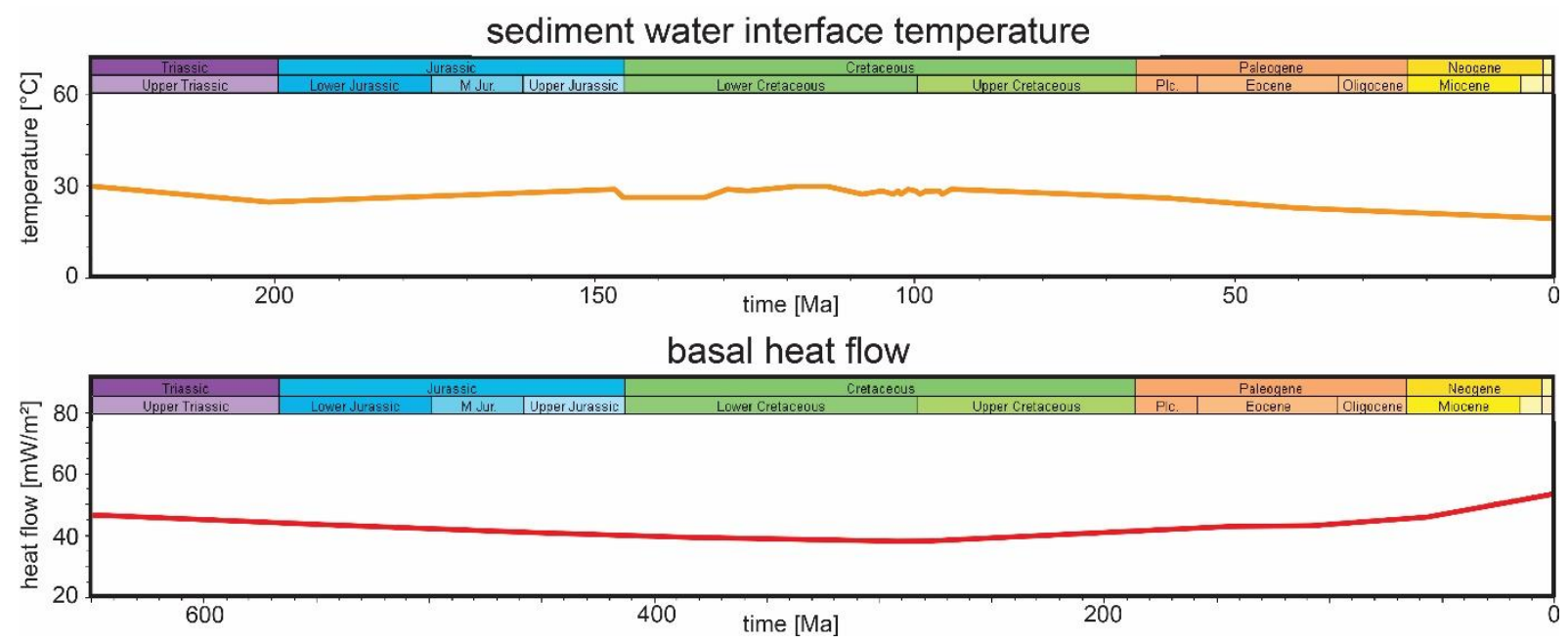

Figure S3: Thermal boundary conditions used for numerical basin modeling. Mean surface temperatures are reconstructed based on plate motion and the changing paleo-latitude (Wygrala, 1989). Basal heat flow was constrained by sensitivity analysis. 

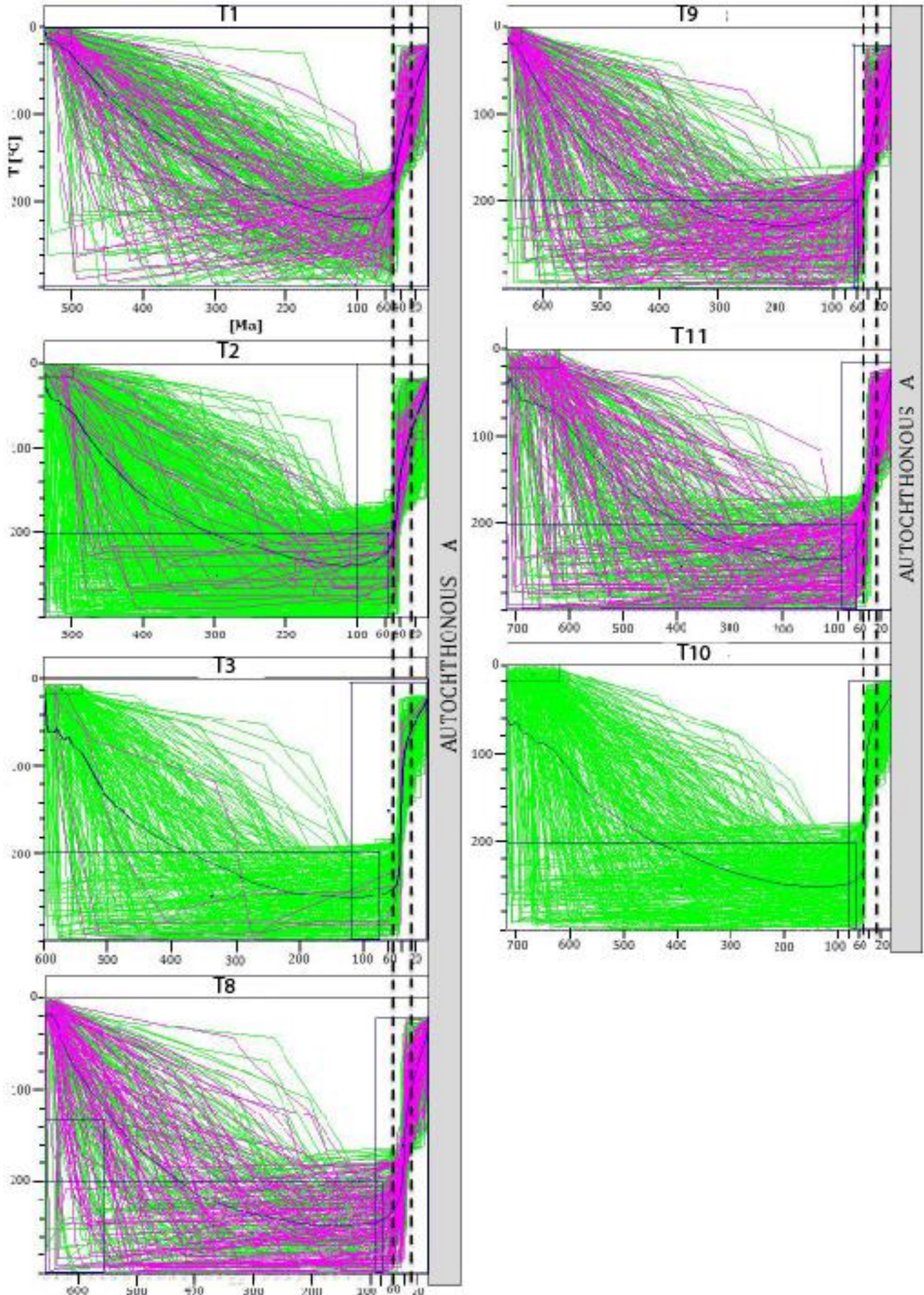

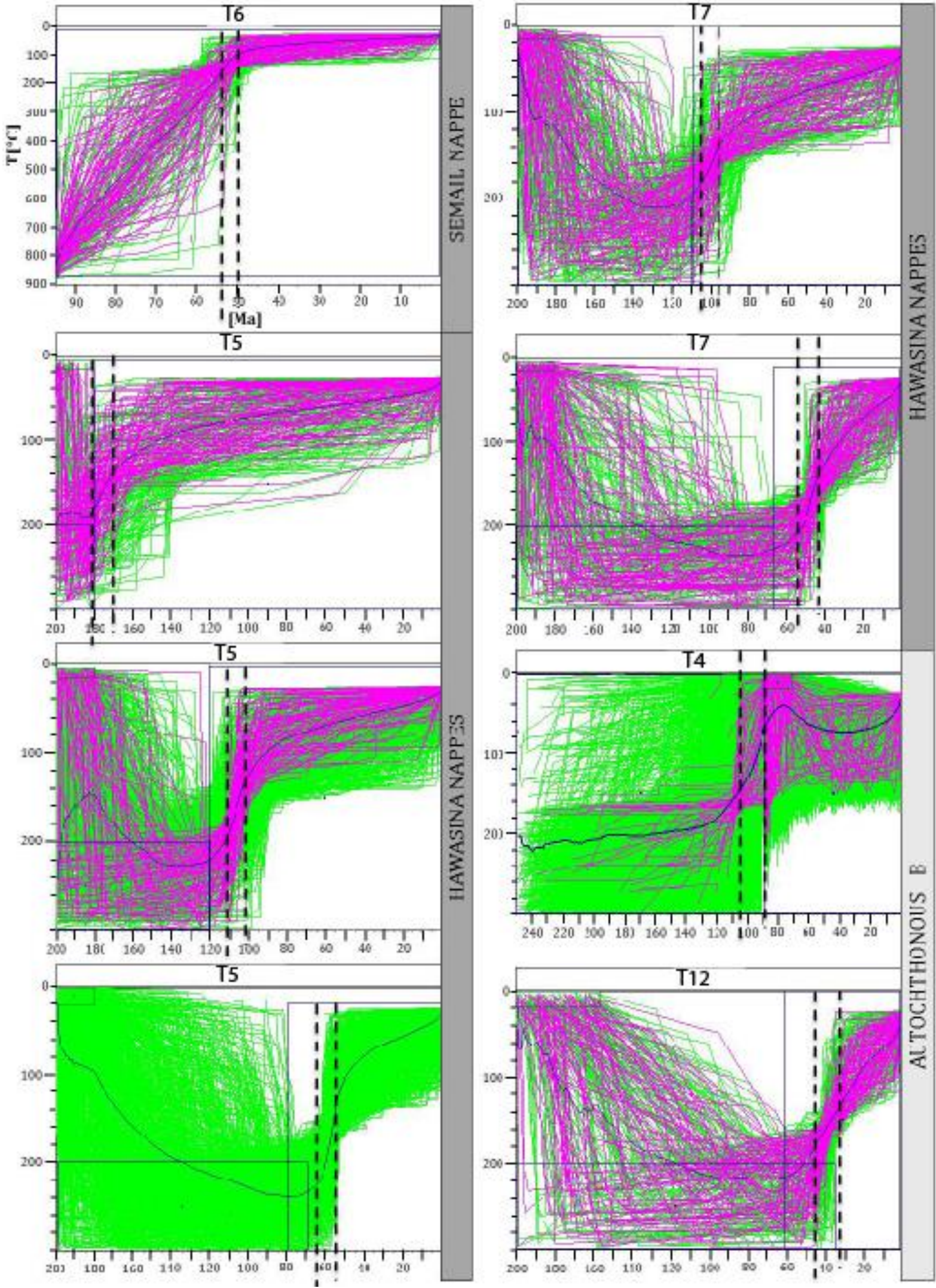

Figure S4 (previous page) and S5: Modeled time-temperature paths of samples of Semail Ophiolite, Hawasina Nappes, Autochthonous $A$ and $B$. The black line represents the weighted mean values of good fits between model and data (purple paths) and acceptable fits (green paths). Models outline rapid cooling until c. $50 \mathrm{Ma}$ in the Ophiolite (A), and main cooling in Hawasina Nappes (C), and Autochthonous A and B (D, E) at c. 50-30 Ma. Modeled paths of the not reset zircons of the Hawasina Nappes are shown in comparison (B). 


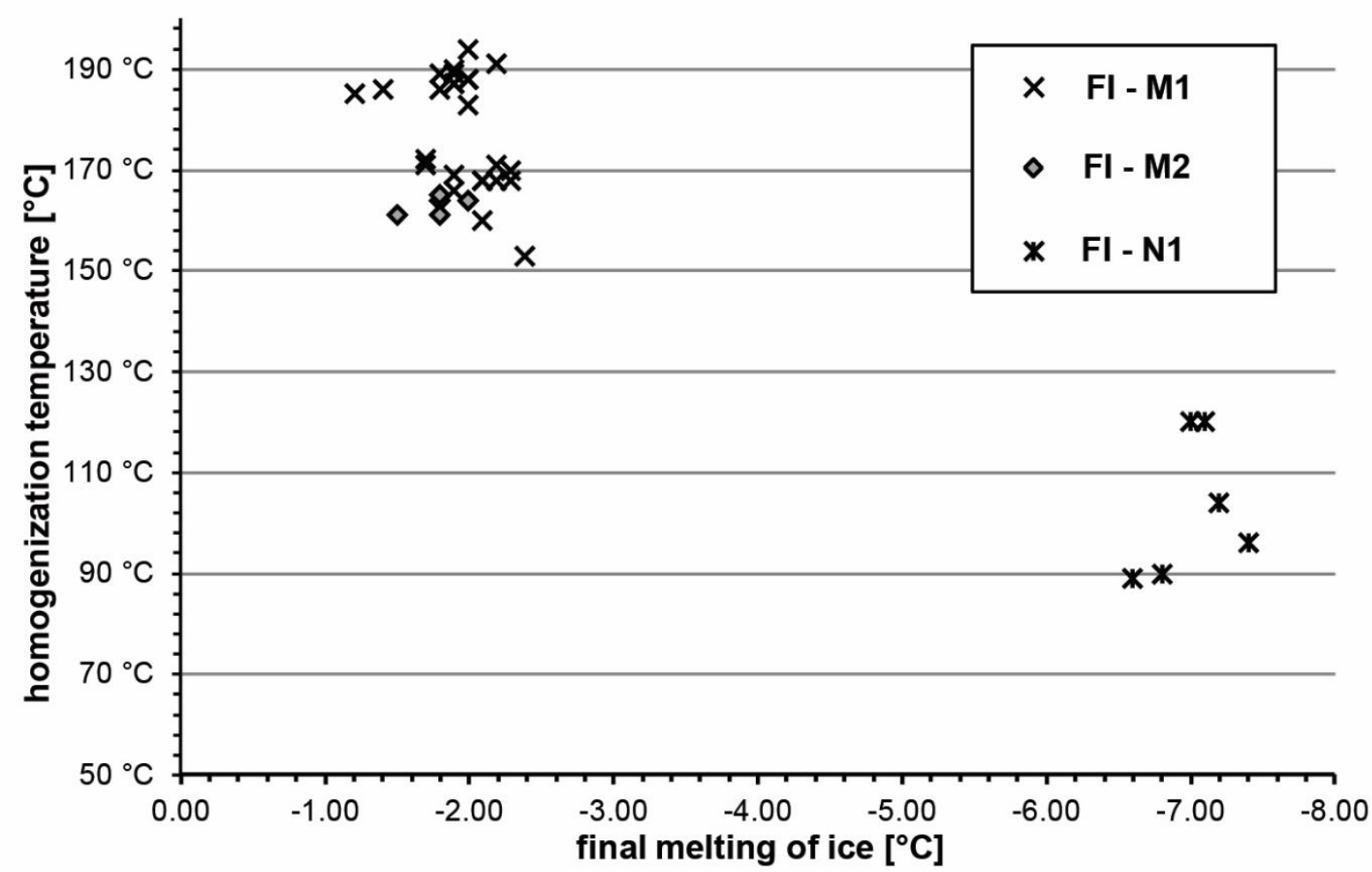

Figure S6: Additional fluid inclusion data plots: homogenization temperatures plotted against the salinities in wt.-\% $\mathrm{NaCl}$ equivalent which are calculated out of the final melting temperature after Bodnar (1993).

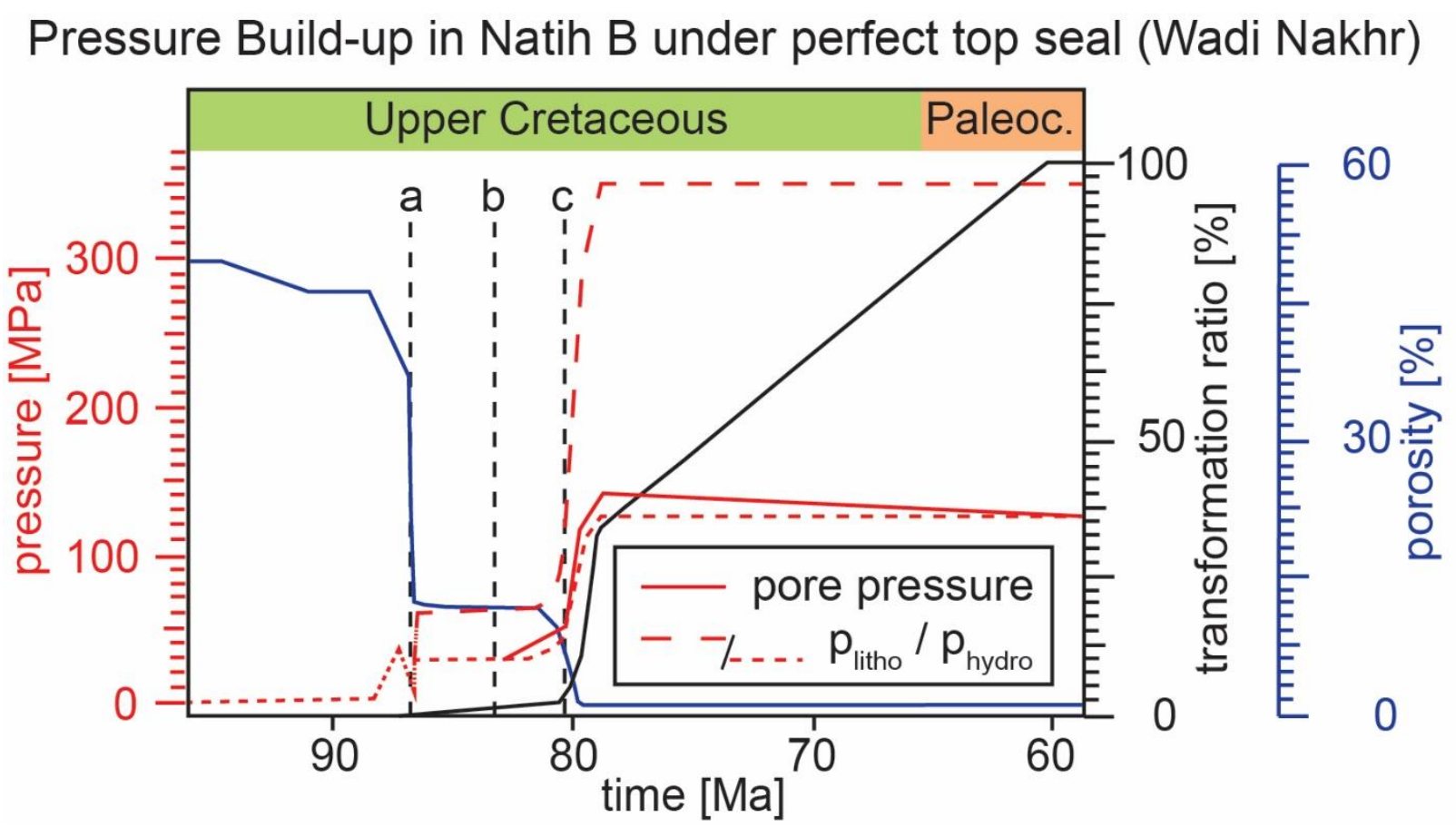

Figure S7: Pressure and porosity model results for the Natih B source rock at Wadi Nakhr with perfect seal conditions $\left(\mathrm{kv}, \mathrm{h}=10-23 \mathrm{~m}^{2}\right)$ assigned to the Muti Fm. (top seal): Porosity loss (blue) over time in response to the moving forebulge (a), the emplacement of sedimentary (b) and ophiolitic nappes (c). Comparison to the transformation ratio (black) outlines overpressure associated with hydrocarbon generation. 

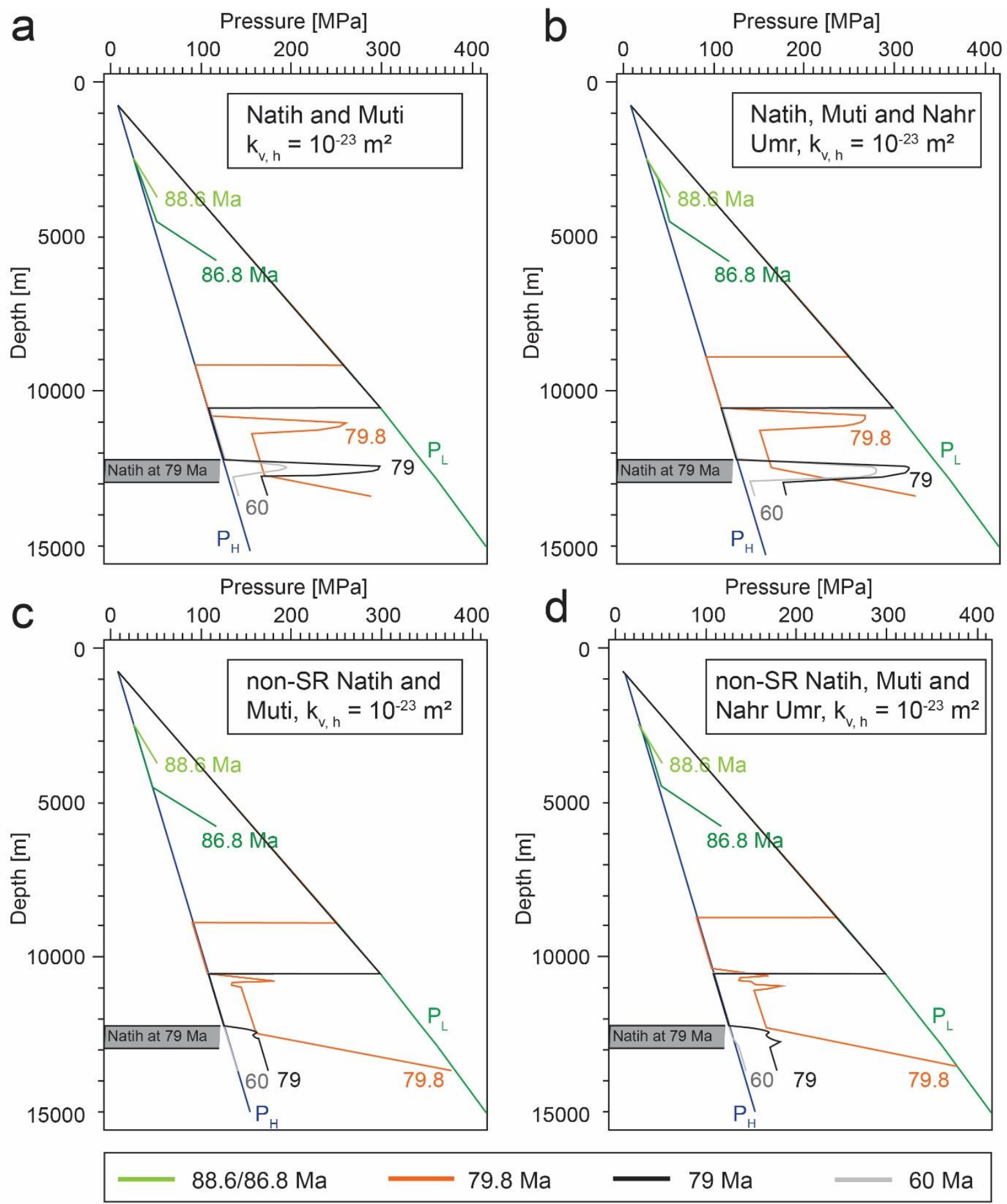

Figure S8: Pressure depth evolution for selected time steps (numbers in Ma) and reduced permeabilities of Muti, Natih and/or Nahr Umr Fm. Lithostatic and hydrostatic pressure lines and the position of the Natih Fm. are shown for peak pressures when deepest burial was reached at $79 \mathrm{Ma}$. Normal permeabilities of a shaly limestone with a porosity of $1 \%$ reached by burial under the ophiolite are in the order of 10-15 $\mathrm{m}^{2}$. 


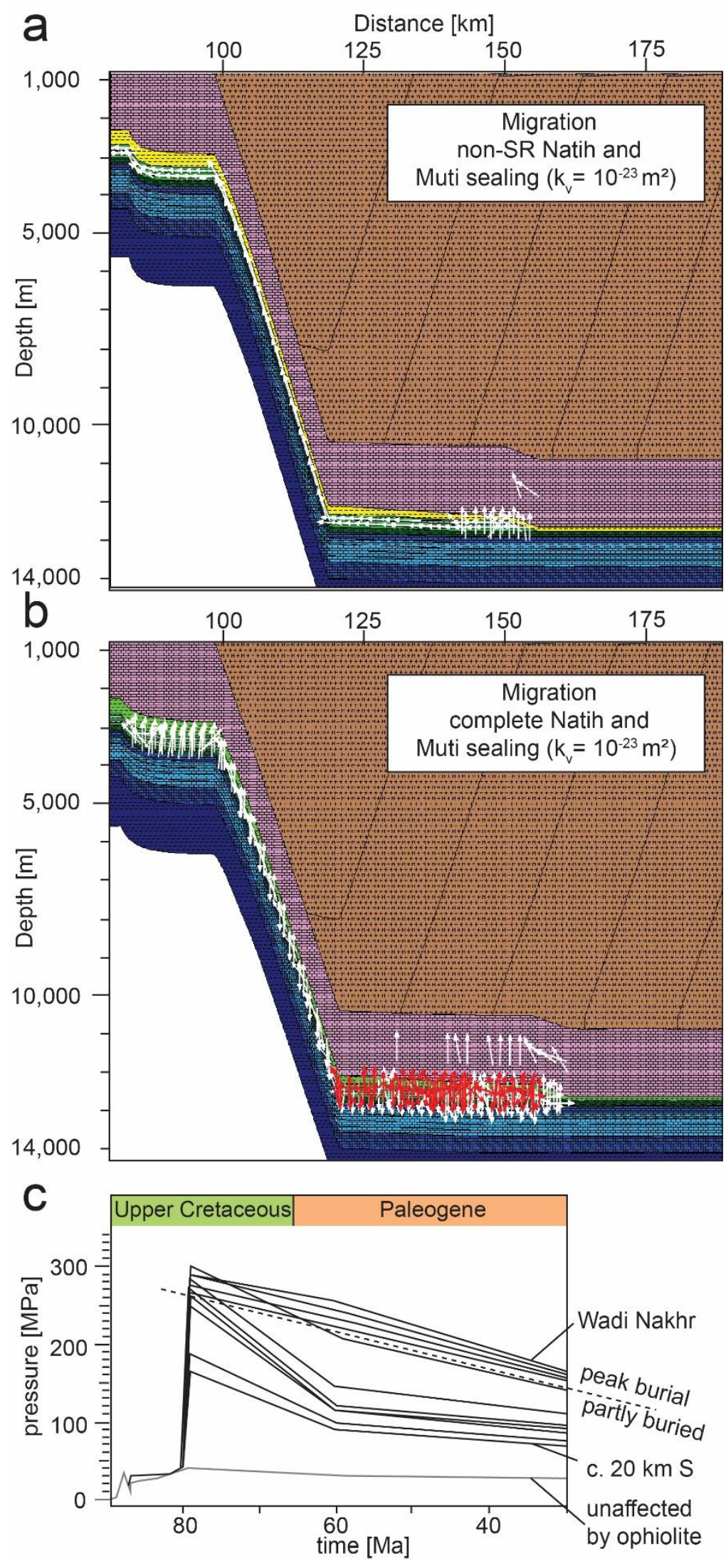

Figure S9: Model results of fluid migration in front of the obducting ophiolite. Migration localizes in the source rock layers of the Natih Fm. if they remain permeable (a) or at layer boundaries if the complete Natih has reduced permeabilites (b). Pressure evolution of the Natih Fm. over time for selected locations underneath the ophiolite (c) show how a pressure gradient established during obduction. The topmost black line represents the location of the Wadi Nakhr, each line below a position $2 \mathrm{~km}$ further south. The gray baseline represents the obduction-uneffected pressure evolution for comparison. 